\title{
Risiko Keuangan Sebagai Determinan Hubungan antara Earning dengan Return pada Bank BUMN
}

\author{
Amilia Paramita Sari \\ Fakultas Ekonomi Universitas Batanghari \\ amiliaps18@gmail.com
}

\begin{abstract}
This research aimed to found whether credit risk could be the earning connection determinant by return within BUMN Banking. The dependent variable of this study is cumulative abnormal return $(C A R)$ whereas independent variable are standardized unexpected earning (SUE), credit risk and interest risk. The sample of this study are BUMN Banking in Indonesia. Data used in this study is secondary one from Annual Report from 2014 to 2017. In order to analized connection between standardized unexpected earning (SUE) to cumulative abnormal return $(C A R)$ and financial risk as connection determinant of both earning by return used double regression analysis. Research result showed that variable of standardized unexpected earning (SUE) have relation to cumulative abnormal return (CAR) and credit risk could be determinant of both earning and return connection. While for interest risk not become determinant of both earning and return connection.
\end{abstract}

Keywords: cumulative abnormal return (CAR), standardized unexpected earning (SUE), credit risk and interest risk.

\section{PENDAHULUAN}

Lembaga keuangan selain sebagai penghimpun dana dari masyarakat, juga merupakan alternatif pendanaan bagi perusahaan (Adriansah dan Simatupang, 1993). Lembaga keuangan memiliki fungsi sebagai penyalur dana, dengan menghimpun dana dari pihak yang mempunyai kelebihan dana dan menyalurkannya kembali ke pihak yang membutuhkan dana (Edward, 2008). Fungsi sebagai penyedia dana ini menyebabkan pengaruh dominan lembaga keuangan terhadap perekonomian dalam hubungannya dengan pendanaan organisasi bisnis atau perusahaan. Namun, penyaluran dana tersebut tidak dikelola dengan baik, bank dapat mengalami kegagalan bahkan pada akhirnya mengalami kebangkrutan. Risiko di dalam konteks bisnis (bank dan lembaga keuangan) tidak selalu mewakili sesuatu hal yang buruk. Risiko dapat menjadi peluang bagi mereka yang mampu mengelolanya dengan baik. Selanjutnya, Morgan dalam Avartara (2007) mengartikan risiko sebagai suatu ketidakpastian dari Net Return yang terjadi, atau secara komprehensif risiko merupakan suatu potensi terjadinya peristiwa (event) yang dapat memberikan pengaruh negatif terhadap nilai suatu fortofolio aset. Hal ini megindikasikan risiko hari ini merupakan potensi kerugian esok hari. Risiko tidak dapat diukur seperti menghitung pendapatan dan biaya yang harus dikeluarkan bank karena risiko bersifat tidak berwujud. (Adisetiawan dan Atikah, 2018)

Pesatnya perkembangan perbankan di Indonesia mengakibatkan sangat diperlukan suatu pengawasan terhadap kinerja bank tersebut (Sari, 2018). Bank Indonesia sebagai bank sentral memiliki suatu kontrol terhadap bank-bank untuk 
mengetahui bagaimana keadaan keuangan serta kegiatan usaha masing-masing bank. Kebijakan perbankan yang dikeluarkan dan dilaksanakan oleh Bank Indonesia pada dasarnya adalah ditujukan untuk menciptakan dan memelihara kesehatan, baik secara individu maupun perbankan secara sistem. Kondisi keuangan dan non keungan bank merupakan kepentingan semua pihak stakeholder, baik pemilik, pengelola (manajemen), masyarakat pengguna jasa bank (nasabah) serta Bank Indonesia selaku otoritas pengawasan bank. Kondisi bank tersebut dapat digunakan oleh pihak-pihak tersebut untuk mengevaluasi kinerja bank (Sari, 2018).

Pada prinsipnya risiko investasi di pasar modal berkaitan dengan kemungkinan terjadinya perubahan harga saham (Wirasari, 2008). Risiko merupakan salah satu faktor yang dipertimbangkan investor dalam berinvestasi dalam pasar modal sehingga informasi risiko menjadi penting. Investor akan cenderung berinvestasi pada perusahaan yang memiliki risiko minimal (Saputra, 2010). Oleh karena itu, risiko menjadi salah satu informasi yang dapat memperjelas hubungan earning dengan return saham. Perusahaan dengan risiko yang lebih rendah akan dinilai baik oleh investor dan pelaku pasar modal yang ditunjukkan dengan perubahan harga positif. (Adisetiawan dan Surono, 2016)

Perubahan harga saham juga dipengaruhi oleh informasi laba. Informasi laba merupakan komponen laporan keuangan perusahaan yang bertujuan untuk menilai kinerja manajemen, membantu mengestimasi kemampuan laba yang representatif dalam jangka panjang, memprediksi laba, dan menaksir risiko dalam investasi atau meminjamkan dana. Laba dipandang sebagai informasi yang penting, karena laba mencerminkan kinerja dan kondisi keuangan perusahaan (Adisetiawan dan Atikah, 2018). Semakin baik kinerja perusahaan maka semakin besar pengaruhnya terhadap kenaikan harga saham. Begitu juga sebaliknya, semakin menurun kinerja perusahaan maka semakin rendah harga saham yang diterbitkan dan diperdagangkan (Sari, 2018). Bagi para analis bisnis, analisis keuangan digunakan untuk menganalisis posisi dan kinerja keuangan perusahaan dengan menggunakan informasi laporan keuangan (Sari, 2015). Perusahaan yang memiliki laba diharapkan akan memberikan dividen dan return yang besar sehingga pasar akan bereaksi positif (Saputra, 2010).

Selain itu, laba juga digunakan sebagai alat untuk mengukur kinerja manajemen perusahaan selama periode tertentu, serta dapat digunakan untuk memperkirakan prospeknya di masa depan (Saputra, 2010). Penelitian ini menggunakan Standardized Unexpected Earning (SUE) atau laba tak terduga sebagai salah satu variabel independennya. Laba tak terduga (SUE) merupakan hasil perhitungan dari laba berjalan dikurangi dengan laba tahun sebelumnya, kemudian dibagi standar deviasi. SUE merupakan salah satu informasi bagi pihak investor untuk mengambil keputusan. (Adisetiawan dan Surono, 2016)

Penelitian ini merupakan replikasi penelitian Ni, et al. (2009) dan Saputra (2010) yang dilakukan untuk melihat hasil penelitian akan memberikan jawaban apakah faktor-faktor risiko keuangan, yaitu risiko kredit dan risiko tingkat suku bunga dapat menjadi faktor penjelas hubungan earning dengan return. Perbedaan peneitian ini dengan penelitian sebelumnya adalah pada sampel, yaitu terbatas 4 (empat) Bank BUMN, yakni PT.Bank Negara Indonesia (Persero) Tbk, PT.Bank Rakyat Indonesia (Persero) Tbk, PT.Bank Mandiri (Persero) Tbk dan PT.Bank Tabungan Negara (Persero) Tbk periode laporan keuangan perusahaan tahun 2014 
sampai dengan 2017, serta variabel yang digunakan pada faktor risiko keuangan adalah risiko kredit dan risiko tingkat suku bunga saja.

Pada penelitian ini, Penulis tertarik untuk melakukan penelitian dan mengambil sampel pada Bank BUMN, karena perusahaan tersebut memiliki fundamental yang kuat, risiko yang lebih kecil, manajemen yang baik, modal yang cukup, nasabah yang banyak dan setia, serta memiliki earning dan return yang cukup besar dibandingkan Bank Non-BUMN.

Tabel 1

Data Cumulative Abnormal Return (CAR), Standardized Unexpected Earning $(S U E)$, Risiko Kredit dan Risiko Tingkat suku bunga

\begin{tabular}{cccccr}
\hline Nama Bank & Tahun Penelitian & CAR & SUE & RK (\%) & RB (\%) \\
\hline BBNI & 2014 & 14.65 & 0.196 & 1.31 & 114.21 \\
& 2015 & 15.42 & 0.156 & 2.25 & 115.03 \\
& 2016 & 14.80 & 0.248 & 2.00 & 113.49 \\
BBRI & 2017 & 14.23 & 0.207 & 1.61 & 119.71 \\
& 2014 & 12.18 & 0.135 & 1.12 & 121.86 \\
& 2015 & 12.88 & 0.049 & 1.53 & 115.13 \\
BMRI & 2016 & 14.63 & 0.032 & 2.08 & 113.73 \\
& 2017 & 14.86 & 0.107 & 2.33 & 113.84 \\
& 2014 & 12.26 & 0.097 & 1.13 & 118.91 \\
BBTN & 2015 & 13.13 & 0.024 & 2.07 & 112.50 \\
& 2016 & 14.77 & 0.307 & 4.04 & 115.35 \\
& 2017 & 15.12 & 0.464 & 2.31 & 111.74 \\
& 2014 & 8.47 & 0.267 & 0.67 & 94.14 \\
& 2015 & 8.07 & 0.616 & 0.66 & 94.54 \\
& 2016 & 8.93 & 0.415 & 0.44 & 100.81 \\
& 2017 & 8.29 & 0.156 & 0.49 & 98.77 \\
\hline
\end{tabular}

Sumber : Data diolah, 2018

Tujuan yang ingin dicapai dalam penelitian ini adalah untuk mengetahui apakah faktor rasio keuangan, yaitu risiko kredit dan risiko tingkat suku bunga dapat menjadi penjelas hubungan earning dengan return saham.

\section{Tinjauan Pustaka}

Return saham adalah yang dinikmati investor atas investasi saham yang dilakukannya (Jogiyanto, 2000). Return tersebut memiliki dua komponen yaitu current income dan capital gain. Bentuk current income berupa keuntungan yang diperoleh melalui pembayaran yang bersifat periodik berupa dividen sebagai hasil kinerja fundamental perusahaan. Sedangkan capital gain berupa keuntungan yang diterima karena selisih antara harga jual dan harga beli saham. Besarnya capital gain suatu saham akan positif, apabila harga jual dari saham yang dimiliki lebih tinggi dari harga belinya. Perubahan harga saham dapat diukur dengan adanya perubahan return sebagai nilai perubahan harga atau dengan menggunakan abnormal return (Norpratiwi, 2003).

Abnormal return adalah Selisih antara tingkat keuntungan yang sebenarnya dengan tingkat keuntungan yang diharapkan. Abnormal return sering digunakan sebagai dasar pengujian efisiensi pasar. Pasar dikatakan efisien jika 
tidak satu pun pelaku pasar yang menikmati abnormal return dalam jangka waktu yang cukup lama. Akan tetapi, abnormal return dapat digunakan untuk melakukan penilaian kinerja surat berharga. Pada dasarnya ada beberapa model untuk menghitung abnormal return, di antaranya market model/single index model dan capital asset pricing model. Kedua model tersebut sulit dilakukan karena harus melakukan estimasi untuk beta, tingkat suku bunga bebas risiko dan return pasar. (Adisetiawan dan Surono, 2016)

Kegiatan di bidang keuangan biasanya dapat diklasifikasikan sebagai kejadian atau informasi harga yang belum atau sesudahnya ada di pasar keuangan. Abnormal return kumulatif, atau Cumulative Abnormal Return (CAR), merupakan jumlah dari semua pengembalian yang abnormal. Norpratiwi (2003) menyatakan bahwa Cumulative Abnormal Return (CAR) merupakan akumulasi abnormal return selama periode peristiwa untuk masing-masing saham. CAR lebih sering digunakan untuk menyelidiki peristiwa yang berpengaruh terhadap harga saham (Suaryana, 2005). CAR merupakan proksi dari harga saham atau reaksi pasar. Variabel yang digunakan dalam penelitian ini adalah data closing price untuk saham dengan periode selama pelaporan. CAR adalah akumulasi return sesungguhnya dikurang return ekspektasi.

Informasi laba menjadi penting karena merupakan salah satu informasi bagi pihak investor untuk mengambil keputusan. Penggunaan informasi laba dapat mengurangi ketidakpastiaan kinerja keuangan perusahaan dimasa depan, sehingga kualitas pengambilan keputusan akan semakin meningkat (Sansaloni dan Monika, 2003). Penelitian ini menggunakan Standardized Unexpected Earning (SUE) sebagai pengukuran informasi laba. Standardized Unexpected Earning merupakan suatu teknik yang digunakan untuk mengukur pendapatan laba tahunan tak terduga, yang akan berpengaruh pada harga dari suatu saham (Gunawan dan Prasetya, 2007). SUE merupakan laba tahun berjalan setelah pajak dikurang laba tahun lalu setelah pajak, dibagi laba tahun lalu setelah pajak.

Risiko kredit merupakan risiko yang timbul akibat ketidakmampuan debitur untuk membayar kembali, atau kemungkinan kerugian yang timbul akibat kegagalan debitur untuk memenuhi kewajibannya terhadap bank (Prisetiyadi, 2007). Risiko kredit merupakan provision for bad and doubtful debts dibagi loans. Risiko tingkat suku bunga merupakan risiko yang muncul akibat perubahan tingkat suku bunga. Risiko tingkat suku bunga merupakan variabilitas pendapatan saham yang disebabkan karena adanya perubahan tingkat suku bunga (Siswanto, 2008). Selanjutnya, risiko ini tidak dapat didiversifikasi karena tingkat suku bunga cenderung naik turun secara bersamaan yang berpengaruh terhadap nilai aktiva secara umum, dan harga saham akan berlawanan dengan perubahan suku bunga tersebut. Risiko tingkat suku bunga merupakan deposits dibagi loans.

\section{Penelitian Terahulu}

Penelitian sebelumnya yang dilakukan oleh Cheng dan Arif (2007), menggunakan faktor risiko keuangan, yaitu risiko kredit, risiko tingkat suku bunga, risiko likuiditas, risiko solvensi sebagai penjelas hubungan earning dan return perbankan di Malaysia. Hasil penelitian menunjukkan bahwa risiko kredit secara signifikan dapat menjadi faktor penjelas hubungan earning dengan return. Penelitian lain dilakukan oleh $\mathrm{Ni}$, et al. (2009), menunjukkan hasil yang berbeda dari penelitian Cheng dan Arif, penelitian $\mathrm{Ni}$, et al. menemukan salah satu faktor 
risiko keuangan, yaitu risiko tingkat suku bunga secara signifikan dapat menjadi faktor penjelas hubungan earning dengan return pada perbankan Thailand. Hasil penelitiannya menemukan bahwa variabel Standardized Unexpected Earning (SUE) mempunyai hubungan positif dan signifikan terhadap Cumulative Abnormal Return (CAR).

Penelitian terdahulu yang dilakukan oleh Saputra (2010) menunjukkan hasil yang berbeda dari penelitian Cheng dan Arif dan sejalan dengan penelitian $\mathrm{Ni}$, et al. yaitu menunjukkan bahwa SUE dan risiko tingkat suku bunga secara signifikan dapat menjadi faktor penjelas hubungan earning dengan return.

\begin{tabular}{|c|c|}
\hline Standardized Unexpected Earning (SUE) \\
\hline Risiko Kredit (RK)
\end{tabular} \mid $\begin{gathered}\text { cumulative abnormal return } \\
(\text { CAR) }\end{gathered}$

Gambar 1. Kerangka Konseptual

\section{METODE}

Metode yang digunakan adalah dengan menggunakan data sekunder. Data kuantitatif merupakan jenis data yang dipergunakan pada penelitian ini yang bersumber dari Annual Report perusahaan yang dipublikasikan melalui masingmasing website perusahaan, sehingga pengumpulan data dalam penelitian ini yaitu menggunakan metode observasi nonpartisipan. Jenis penelitian ini adalah penelitian kuantitatif dengan menggunakan pendekatan studi kasus (case study). Sampel pada penelitian ini terdiri dari 4 (empat) Bank BUMN yang memiliki data keuangan lengkap dari tahun 2014 sampai dengan tahun 2017.

Tabel 2

Sampel Penelitian

\begin{tabular}{ccl}
\hline No & Kode & \multicolumn{1}{c}{ Nama Emiten } \\
\hline 1 & BBNI & PT Bank Negara Indonesia (Persero) Tbk \\
2 & BBRI & PT Bank Rakyat Indonesia (Persero) Tbk \\
3 & BMRI & PT Bank Mandiri (Persero) Tbk \\
4 & BBTN & PT Bank Tabungan Negara (Persero) Tbk \\
\hline
\end{tabular}

Sumber : Data diolah, 2018

Metode Analisis Data, adapun alat uji statistik yang digunakan dalam penelitian ini adalah menggunakan aplikasi SPSS v.20. Karena data yang digunakan data sekunder, maka untuk menentukan ketepatan model perlu dilakukan pengujian atas beberapa asumsi klasik yang mendasari model regresi. Model regresi linier berganda dapat disebut sebagai model yang baik jika model tersebut memenuhi asumsi normalitas data dan terbebas dari asumsi klasik statistik, baik itu multikolinieritas, autokorelasi dan heteroskedatisitas. 
Koefisien determinasi $\left(\mathrm{R}^{2}\right)$ bertujuan untuk mengetahui seberapa besar kemampuan variabel independen menjelaskan variabel dependen. Koefisien determinasi terletak pada Model Summary ${ }^{\mathrm{b}}$ dan tertulis R Square. Namun untuk regresi linier berganda sebaiknya mengunakan $\mathrm{R}$ Square yang sudah disesuaikan atau ditulis Adjusted R Square, karena disesuaikan dengan jumlah variabel independen yang digunakan dalam penelitian. Nilai $\mathrm{R}$ Square dikatakan baik jika di atas 0,5 karena nilai R Square berkisar antara 0 sampai 1 . Uji Simultan dengan F-Test (ANOVA), hasilnya menunjukkan variabel independen secara bersamasama berpengaruh terhadap variabel dependen jika $\mathrm{F}$ hitung lebih besar dari $\mathrm{F}$ tabel. Uji Parsial dengan T-Test bertujuan untuk mengetahui besarnya pengaruh masing-masing variabel independen secara individual (parsial) terhadap variabel dependen.

\section{Operasional Variabel} berikut:

Operasional Variabel yang digunakan dalam penelitian ini adalah sebagai

1. Variabel Independen (X)

Variabel independen yang digunakan dalam penelitian ini yaitu standardized unexpected earning (SUE) dan risiko keuangan, yakni risiko kredit dan risiko tingkat suku bunga.

2. Variabel Dependen (Y)

Variabel dependen dalam penelitian ini adalah cumulative abnormal return (CAR).

\section{HASIL}

\section{Uji Asumsi Klasik Statistik}

Uji normalitas bertujuan untuk menguji apakah model regresi variabel dependen dan independen atau keduanya memiliki distribusi normal atau mendekati normal. Pada Tabel 3, jika nilai probabilitas (sig) Kolmogorov-Smirnov lebih besar dari $(>) \alpha=0,05$, maka hal ini menunjukkan bahwa data terdistribusi secara normal, maka model regresi dapat dikatakan memenuhi asumsi normalitas. Hal ini menunjukkan bahwa uji normalitas telah terpenuhi.

Tabel 3

One-Sample Kolmogorov-Smirnov Test

\begin{tabular}{|ll|r|}
\hline & & Unstandardized Residual \\
\hline $\mathrm{N}$ & & 16 \\
Normal Parameters $^{\mathrm{a}, \mathrm{b}}$ & Mean & $0 \mathrm{E}-7$ \\
& Std. Deviation & .02995542 \\
& Absolute & .107 \\
Most Extreme Differences & Positive & .107 \\
& Negative & -.103 \\
Kolmogorov-Smirnov Z & & .428 \\
Asymp. Sig. (2-tailed) & & .993 \\
\hline
\end{tabular}

a. Test distribution is Normal.

b. Calculated from data. 
Uji multikolineritas bertujuan untuk menguji apakah model regresi ditemukan adanya korelasi antar variabel independen. Model regresi yang baik seharusnya tidak terjadi korelasi diantara variabel independen. Hasil dari pengujian multikolineritas diperoleh bahwa tiga variabel tersebut memiliki angka VIF < 10 dan nilai tolerance $>0.10$ maka tidak terjadi adanya gejala multikolineritas.

Tabel 4

Uji Multikolinearitas

\begin{tabular}{|c|c|c|c|c|c|c|}
\hline \multirow{2}{*}{\multicolumn{2}{|c|}{ Model }} & \multicolumn{2}{|c|}{ Unstandardized Coefficients } & \multirow{2}{*}{$\frac{\text { Standardized Coefficients }}{\text { Beta }}$} & \multicolumn{2}{|c|}{ Collinearity Statistics } \\
\hline & & $\mathrm{B}$ & Std. Error & & Tolerance & VIF \\
\hline \multirow{4}{*}{1} & (Constant) & -1.452 & 1.003 & & & \\
\hline & SUE & 1.228 & .500 & .422 & .234 & 4.267 \\
\hline & $\mathrm{RK}$ & .224 & .056 & .591 & .317 & 3.158 \\
\hline & RB & .008 & .074 & .022 & .148 & 6.769 \\
\hline
\end{tabular}

Uji autokorelasi bertujuan untuk mengetahui apakah terjadi korelasi antara anggota serangkaian data observasi yang diurutkan menurut waktu (time series). Hasil dari pengujian autokorelasi pada penelitian ini diperoleh nilai table di Durbin Watson (DW) didapat nilai dl sebesar 0,715 dan nilai du sebesar 1,816. Hasil output SPSS nilai Durbin Watson (DW) 2,164. Oleh karena nilai (du < DW $<4$-du) atau $(1,816<2,164<2,184)$ maka dapat disimpulkan tidak adanya autokorelasi.

\section{Tabel 5}

Uji Aukokorelasi

Model Summary ${ }^{b}$

\begin{tabular}{|l|r|r|r|r|r|}
\hline Model & R & R Square & Adjusted R Square & Std. Error of the Estimate & Durbin-Watson \\
\hline 1 & $.958^{\mathrm{a}}$ & .917 & .896 & .0334912 & 2.164 \\
\hline
\end{tabular}

a. Predictors: (Constant), RB, RK, SUE

b. Dependent Variable: CAR

Uji Heteroskedastisitas bertujuan untuk menguji apakah dalam model regresi terjadi ketidaksamaan variance dari residual satu pengamatan ke pengamatan yang lain. Pada Gambar 5 terlihat bahwa Grafik scatterplot terlihat bahwa titik-titik menyebar secara acak serta tersebar baik diatas maupun dibawah angka nol (0) pada sumbu Y, tidak terkumpul disuatu tempat, serta tidak membentuk pola tertentu sehingga dapat disimpulkan bahwa tidak terjadi heteroskedastisitas pada model regresi. 


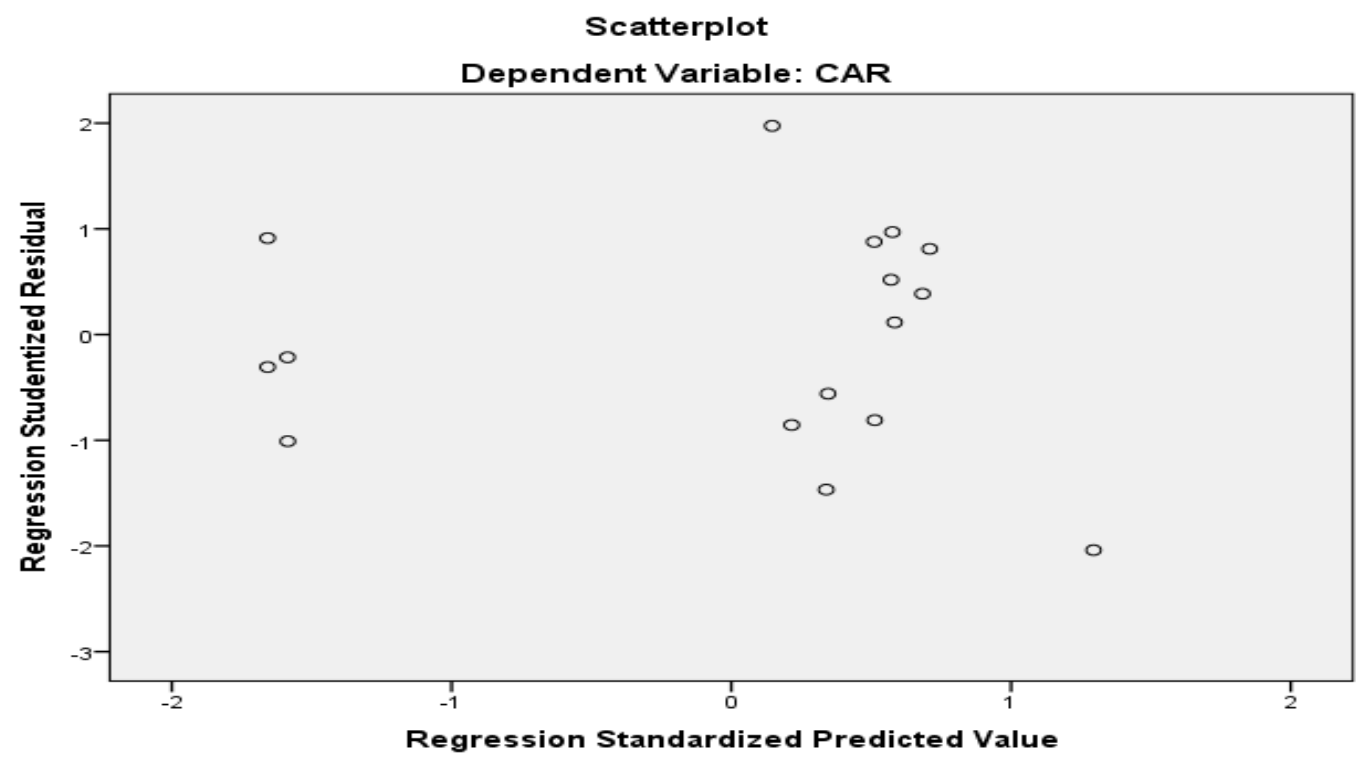

Gambar 2

Uji Heteroskedastisitas

\section{Uji Regresi Linier Berganda}

Analisis statistik yang digunakan dalam penelitian ini adalah regresi linier berganda. Analisis ini digunakan untuk mengetahui besarnya pengaruh variabel bebas (independen) yaitu SUE, RK dan RB terhadap variabel terikat (dependen) yaitu CAR. Besarnya pengaruh variabel independen terhadap variabel dependen secara bersama-sama dapat dihitung melalui suatu persamaan regresi linier berganda. Berdasarkan perhitungan melalui komputer dengan menggunakan SPSS diperoleh hasil sebagai berikut:

Tabel 6

Hasil Estimasi Regresi Coefficients $^{a}$

\begin{tabular}{|rl|r|r|r|}
\hline \multirow{2}{*}{ Model } & \multicolumn{2}{|c|}{ Unstandardized Coefficients } & \multicolumn{2}{c|}{ Standardized Coefficients } \\
\cline { 3 - 5 } & & \multicolumn{2}{|c|}{ Std. Error } & \multicolumn{2}{c|}{ Beta } \\
\hline \multirow{4}{*}{1} & (Constant) & -1.452 & 1.003 & .422 \\
& SUE & 1.228 & .500 & .591 \\
& RK & .224 & .056 & .022 \\
\hline
\end{tabular}

Dependent Variable: CAR

Berdasarkan Tabel 6 dapat dilihat hubungan variabel SUE, RK dan RB (independen) terhadap CAR (dependen). Sehingga dapat diketahui persamaan regresi yang terbentuk adalah sebagai berikut:

$\mathrm{Y}=-1.452 \mathrm{CAR}+1.228 \mathrm{SUE}+0,224 \mathrm{RK}+0,008 \mathrm{RB}$

\section{Analisis Koefisien Determinasi (Goodness of Fit)}

Hasil pengujian pada Tabel 6, didapat nilai adjusted $R$ square sebesar 0,896 atau $86,9 \%$; yang berarti variasi dari CAR dapat dijelaskan oleh variasi dari ketiga variabel SUE, RK dan RB, sedangkan sisanya sebesar 13,1\% dijelaskan 
oleh perubahan variabel lain di luar model penelitian. Nilai koefisien korelasi $(R$ Squere) diperoleh sebesar 0,917 menunjukkan bahwa hubungan antara variabel independen terhadap variabel dependen adalah signifikan (kuat) yaitu sebesar $91,7 \%$.

Tabel 7

Koefisien Determinasi

\begin{tabular}{|l|r|r|r|r|}
\hline Model & R & \multicolumn{1}{|c|}{ R Square } & Adjusted R Square & Std. Error of the Estimate \\
\hline 1 & $.958^{\mathrm{a}}$ & .917 & .896 & .0334912 \\
\hline
\end{tabular}

\section{Uji F-test (Uji Determinant F)}

Uji F-test dimaksudkan untuk mengetahui pengaruh variabel independen

(SUE, RK dan RB) secara simultan (bersama-sama) terhadap CAR pada tahun 2014-2017.

Tabel 8

Hasil Uji F-test

ANOVA ${ }^{\mathrm{a}}$

\begin{tabular}{|ll|r|r|r|r|r|}
\hline Model & Sum of Squares & df & Mean Square & F & Sig. \\
\hline \multirow{2}{*}{1} & Regression & .149 & 3 & .050 & 44.192 & $.000^{\mathrm{b}}$ \\
& Residual & .013 & 12 & .001 & & \\
& Total & .162 & 15 & & & \\
\hline
\end{tabular}

a. Dependent Variable: CAR

b. Predictors: (Constant), RB, RK, SUE

Hasil perhitungan diperoleh nilai F.hitung > F.tabel $(44,192>3,41)$ dengan tingkat signifikan sebesar 0.000 . Hal ini berarti nilai signifikan lebih kecil dari tingkat kepercayaan 5\% yang menunjukkan hasil uji anova ini dapat disimpulkan bahwa variabel SUE, RK dan RB secara bersama-sama mempunyai pengaruh terhadap CAR dan dapat disimpulkan bahwa model dalam penelitian ini layak untuk diteliti (goodness of fit).

\section{Uji t-test (Parsial)}

Secara parsial pengaruh dari tiga variabel independen SUE, RK dan RB) terhadap CAR ditunjukkan pada tabel 9 sebagai berikut:

\section{Tabel 9}

Hasil Uji t-test

Coefficients $^{\mathrm{a}}$

\begin{tabular}{|c|c|c|c|c|c|c|c|}
\hline \multirow[t]{2}{*}{ Model } & \multicolumn{2}{|c|}{$\begin{array}{c}\text { Unstandardized } \\
\text { Coefficients }\end{array}$} & \multirow{2}{*}{$\begin{array}{c}\begin{array}{c}\text { Standardized } \\
\text { Coefficients }\end{array} \\
\text { Beta }\end{array}$} & \multirow[t]{2}{*}{$\mathrm{t}$} & \multirow[t]{2}{*}{ Sig. } & \multicolumn{2}{|c|}{ Collinearity Statistics } \\
\hline & $\mathrm{B}$ & Std. Error & & & & Tolerance & VIF \\
\hline (Constant) & -1.452 & 1.003 & & -1.447 & .174 & & \\
\hline SUE & 1.228 & .500 & .422 & 2.457 & .030 & .234 & 4.267 \\
\hline RK & .224 & .056 & .591 & 4.000 & .002 & .317 & 3.158 \\
\hline $\mathrm{RB}$ & .008 & .074 & .022 & .101 & .921 & .148 & 6.769 \\
\hline
\end{tabular}

a. Dependent Variable: CAR 
Berdasarkan hasil uji parsial pada Tabel 9, dapat diketahui bahwa secara parsial, Standardized Unexpected Earning (SUE) dan risiko kredit berpengaruh terhadap Cumulative Abnormal Return (CAR) pada Bank BUMN periode 2014 sampai 2017, sedangkan variabel risiko tingkat suku bunga tidak berpengaruh signifikan. Hasil uji secara parsial (uji-t) untuk Standardized Unexpected Earning $(S U E)$ menunjukkan nilai t.hitung >t.tabel $(2,457>1,771)$ dan nilai signifikansi di bawah $0,05(0,030<0,05)$ yang berarti terdapat pengaruh signifikan antara SUE terhadap variabel CAR. Hasil penelitian ini mendukung penelitian $\mathrm{Ni}$, et al. dan Saputra yang menyatakan bahwa SUE berpengaruh terhadap CAR dan menolak penelitian Cheng dan Arif. Hasil uji secara parsial (uji-t) untuk Risiko Kredit menunjukkan nilai t.hitung >t.tabel $(4,000>1,771)$ dan nilai signifikansi di bawah $0,05(0,002<0,05)$ yang berarti terdapat pengaruh signifikan antara Risiko Kredit terhadap variabel CAR. Hasil penelitian ini mendukung penelitian Cheng dan Arif yang menyatakan bahwa Risiko Kredit berpengaruh terhadap CAR dan menolak penelitian Ni, et al. dan Saputra. Hasil uji secara parsial (uji-t) untuk Risiko Tingkat Suku Bunga menunjukkan nilai t.hitung $<$ t.tabel $(0,101<1,771)$ dan nilai signifikansi di atas $0,05(0,921>0,05)$ yang berarti tidak terdapat pengaruh signifikan antara Risiko Tingkat Suku Bunga terhadap variabel CAR. Hasil penelitian ini mendukung penelitian $\mathrm{Ni}$, et al. dan Saputra yang menyatakan bahwa Risiko Tingkat Suku Bunga berpengaruh terhadap CAR dan menolak penelitian Cheng dan Arif.

\section{SIMPULAN}

Hasil pembahasan sebelumnya, dapat disimpulkan bahwa secara simultan, Standardized Unexpected Earning ( $S U E$ ), Risiko Kredit dan Risiko Tingkat Suku Bunga secara bersama-sama berpengaruh signifikan terhadap Cumulative Abnormal Return (CAR). Secara parsial, hanya Risiko Tingkat Suku Bunga yang tidak berpengaruh terhadap CAR, sedangkan SUE dan Risiko Kredit berpengaruh terhadap CAR. Hal ini membuktikan bahwa Risiko Keuangan, yakni Risiko Kredit dapat menjadi penjelas hubungan earning dan return saham. Secara teoritis, hasil penelitian ini berimplikasi pada pengembangan akuntansi keuangan yang berkaitan dengan teori efisiensi pasar pada perbankan di Indonesia, karena dari hasil penelitian ini menunjukkan adanya hubungan return saham dengan Unexpected Earning, dan risiko tingkat suku bunga mempunyai informasi bagi investor untuk pengambilan keputusan. Penelitian ini berimplikasi pada sektor perbankan mengenai pengaruh risiko keuangan yang dapat menjadi penjelas hubungan earning dengan return, sehingga dapat membantu perbankan menerapkan strategi dalam menganalisis risiko keuangan yang dapat meningkatkan pendapatan serta kinerja perbankan secara keseluruhan. Selain itu bagi investor, dapat memberikan masukan tambahan tentang sejauh mana pengaruh faktor-faktor risiko keuangan dapat menjadi penjelas hubungan earning dengan return yang dapat digunakan sebagai pertimbangan dalam pengambilan keputusan.

\section{DAFTAR PUSTAKA}

Adisetiawan, R., dan Atikah, 2018, Does Stock Split Influence to Liquidity and Stock Return?, (Empirical Evidence in The Indonesian Capital Market), Asian Economic and Financial Review, 8(5): 682-690 
Adisetiawan, R., dan Surono, Yunan., 2016, Earning Management and Accounting Information Value: Impact and Relevance, Business, Managemen and Economics Research, 2(10): 170-179

Adriansah, A. dan Simatupang, L. (1993), Lembaga Keuangan Indonesia, Institut Banking Indonesia, Edisi 1.

Avartara, 2007. Risiko-risiko Perbankan, http://avartara.com/risiko-risikoperbankan, di akses 20 Agustus 2018.

Cheng, F. F, and Arif M. 2007. Abnormal returns of bank stocks and their factoranalysed determinants. "Journal of Accounting, Bussiness and management April 2007. Vol 14, 1-15.

Edward, S. dan Ramora. 2008. Lembaga Keuangan Non-Bank dan Bank (Perusahaan Keuangan) di Indonesia. http://garis-garis.wordpress.com, di akses 21 Agustus 2018.

Jogiyanto. 2000. Teori Portofolio dan Analisis Investasi. Edisi 2 BPFE, Yogyakarta.

Ni, S. W. Fah, C. F., and Nassir, A, Md. 2009. The Effect of Financial Risk on the Earning Response in Thailand Banks Stock International Research. Journal of Finance and Economics, ISSN 1450-2887 Issue 31.

Norpratiwi, A. M.V. 2003. Analisis Korelasi Investasi Opportuity Set Terhadap Return Saham. Skripsi STIE YKPN Yogyakarta.

Prisetyadi, A. 2007. Risiko Intermediasi Keuangan dalam Pembentukan Portopolio Pinjaman. http://astarhadi.blogspot.com/2007/03/risikointermediasi-keuangan-dalam.html. diakses 26 Agustus 2018.

Sarsaloni, B. dan Monika. P, 2003. Tingkat Kompetensi dan Resiko: Suatu Pengujian Sensitivitas Return Saham Terhadap Laba. Jurnal Akuntansi Bisnis, Vol 2, No 3, Hal 61-72.

Siswanto, A. 2008. Analisis Pengaruh Asset Size, Asset Growth, Leverage, dan Liquidity Terhadap resiko Investasi Saham Anggota Liquidity 45 di Bursa Efek Indonesia. Skripsi Universitas Kristen Petra Surabaya.

Suharyadi dan Purwanto, 2003. Statistika Untuk Ekonomi dan Keuangan Modern. Buku I. Penerbit Salemba Empat Jakarta.

Sari, Amilia P. (2014), Analisis Income Smoothing terhadap Kinerja Pasar dan Reaksi Pasar pada Industri Perbankan di BEI, Jumal Ekotrans, Vol.15 No.2 Juli 2015, ISSN 1411- 4615.

Sari, Amilia P. (2018), Analisis Pengaruh Kinerja Keuangan Terhadap Tingkat Kesehatan Bank Syariah dengan Menggunakan Metode RGEC, Jurnal of Economics and Business, Vol.2 No.1 Maret 2018.

Sari, Amilia P. (2018), Analisis Faktor Fundamental dan Laba Akuntansi terhadap Harga Saham pada Sub Sektor Lembaga Pembiayaan di BEI, Jurnal Manajemen dan Sains, Vol.3 No.1 April 2018.

Wirasari, H. Y. 2008. Pengaruh Perataan Laba Terhadap Resiko Investasi pada Perusahaan yang Terdaftar di BEI. Skripsi Fakultas Ekonomi Jurusan Akuntansi. Universitas Surakarta.

Risiko Keuangan Sebagai Determinan Hubungan antara Earning dengan Return pada Bank BUMN 